\title{
Hubungan Pendapatan, Total Pengeluaran, Proporsi Pengeluaran Pangan dengan Status Ketahanan Rumah Tangga Petani Gurem (Studi di Desa Nogosari Kecamatan Rambipuji Kabupaten Jember)
}

\section{Association between Household Income, Total Expenditure, Proportion of Food Expenditure and Food Security of Small Holder Farmers (Study in Nogosari Village, Rambipuji Sub-district, Jember District)}

\author{
Isma Nur Amalia*1 ${ }^{1}$, Trias Mahmudiono ${ }^{1}$
}

\begin{abstract}
ABSTRAK
Latar belakang: Terwujudnya ketahanan pangan rumah tangga menjadi salah satu indikator pembangunan nasional. Upaya untuk meningkatkan ketahanan pangan dengan pemenuhan pangan masyarakat di bawah kemiskinan yang didominasi oleh petani gurem.

Tujuan: penelitian adalah menganalisis tingkat ketahanan pangan rumah tangga menurut akses ekonomi yang terdiri dari pendapatan, total pengeluaran, proporsi pengeluaran pangan.

Metode: Penelitian menggunakan desain cross sectional dengan besar sample sebesar 51 rumah tangga yang diambil melalui metode propotional sampling yang telah mewakili 7 kelompok tani. Analisis data menggunakan uji statistik spearman dan chi-square.

Hasil: terdapat hubungan pendapatan $(p$-value $=<0,001)$, total pengeluaran $(p$-value $=0,001)$ dan proporsi pengeluaran pangan $(p$-value $=0,001)$ dengan status ketahanan pangan rumah tangga petani gurem.

Kesimpulan: Semua variabel yakni pendapatan, total pengeluaran dan proporsi pangan berhubungan dengan tingkat ketahanan pangan rumah tangga petani gurem.
\end{abstract}

Kata Kunci: Akses Ekonomi, Petani Gurem, Ketahanan Pangan

\section{ABSTRACT}

Background: The realization of household food security is one of the indicators of national development. Efforts to improve food security by the fulfillment of food people on poverty dominated by smallholders.

Objectives: of this research is to analyze the level of household food security according to income, expenditure and proportion of food of smallholder farmers.

Methods: This study used cross sectional design with 51 sample households taken through propotional sampling method which has represented 7 farmer groups. Then the data analysis used by spearman and chi-square statistic test.

Result: This result showed relation between income $p$-value $=0.001(p<0.05)$, household food expenditure $p=0.001(p<0.05)$ and proportion of household food expenditure $p=0.001(p<0.05)$ and household food security status.

Conclusion: All variable are income, expenditure and proportion of food related to the level of food security of smallholder households.

Keywords: Food Security, Smallholder Farmer, Economic Access 
*Koresponden:
isma.amalia1@gmail.com
${ }^{1}$ Departemen Gizi Kesehatan, Fakultas
Kesehatan Masyarakat-Universitas Airlangga

\section{PENDAHULUAN}

Menurut Undang-Undang No. 7 tahun 1996, pembangunan nasional dapat tercemin melalui pemenuhan kebutuhan pangan yang merupakan hak asasi manusia ${ }^{1}$. Kondisi yang mempengaruhi tujuan tercapainya ketahanan pangan adalah kemiskinan yang dikaitkan dengan kemampuan daya beli masyarakat dalam mengakses pangan ${ }^{2}$. Menurut Badan Pusat Statistik (BPS), fenomena kemiskinan di Indonesia masih tergolong tinggi yakni sebesar 28,01 juta jiwa penduduk Indonesia berada pada kondisi miskin ${ }^{3}$. Sebagian besar penduduk miskin didominasi oleh penduduk yang bekerja di sektor pertanian ${ }^{4}$. Menurut laporan pembangunan dunia, tiga dari empat orang miskin tinggal di pedesaan dan bermata pencaharian sebagai petani dan cenderung bekerja sebagai buruh tani dan petani gurem, yang bekerja sebagai buruh di lahan orang lain atau menggarap lahan yang sangat sempit. Tingginya angka kemiskinan disebabkan oleh rendahnya pendapatan yang diterima oleh petani akibat risiko gagal panen, modal yang besar, produksi yang rendah dan sistem harga pasar yang tidak dapat diprediksi ${ }^{6}$. Faktor lain karena kurangnya keberlanjutan pekerjaan petani karena bekerja secara musiman ${ }^{7}$.

Permasalahan yang dialami oleh petani ditambah dengan kondisi lahan pertanian di Indonesia yang semakin menurun ${ }^{6}$. Penurunan lahan pertanian mengakibatkan banyaknya petani yang menggarap lahan dengan luas lahan yang sempit $(<0,5 \mathrm{ha})$ yang disebut petani gurem ${ }^{8}$. Penurunan lahan ini yang menambah risiko tingginya angka kemiskinan ${ }^{9}$. Sebagian rumah tangga miskin pada subsektor pangan adalah buruh tani dan petani gurem yang menyumbang angka sebesar $99,7 \%{ }^{10}$. Hal ini dikarenakan petani yang berlahan kecil (smallholder farmer) memiliki karateristik yakni produksi yang rendah, sistem semi subsisten, produktivitas yang rendah, kurangnya adaptasi teknologi, manajemen, tidak cukupnya akses pasar, dan lebih rentan dengan perubahan musim ${ }^{11}$.

Dalam pengertian sempit, kemiskinan adalah ketidakcukupan uang dan barang untuk melanjutkan hidup seseorang ${ }^{12}$. Tingkat kesejahteraan masih menjadi perhatian karena semakin lama kesejahteraan petani semakin menurun sehingga pembangunan dalam sektor pertanian dimulai dengan meningkatkan kesejahteraan petani $i^{13}$. Rendahnya pendapatan menjadi salah satu indikator rendahnya akses ekonomi petani gurem dengan keterbatasan lahan untuk produksi ${ }^{[14]}$. Pendapatan menjadi faktor ukuran ketahanan pangan dengan melihat kemampuan beli rumah tangga dalam mengakses pangan ${ }^{15}$.

Selain pendapatan rumah tangga, pengeluaran rumah tangga juga menjadi indikator kesejahteraan rumah tangga ${ }^{15}$. Proporsi pengeluaran pangan yang semakin tinggi akan membuat rumah tangga menjadi tidak sejahtera ${ }^{16}$. Hal ini sejalan dengan penelitian Agbola (2014) yang menyebutkan bahwa total pendapatan, dan besar pengeluaran pangan akan memiliki hubungan dengan status ketahanan pangan rumah tangga petani berlahan kecil di Nigeria, Afrika $^{17 .}$.

Kabupaten Jember merupakan kabupaten yang mempunyai nilai surplus dalam ketersedian pangan namun akses pangan yang rendah ${ }^{18}$. Kabupaten Jember yang memiliki potensi geografis pada sektor pertanian ${ }^{19}$. Kecamatan Rambipuji menjadi kecamatan yang memiliki potensi geografis pertanian dengan yang memiliki lahan pertanian yang luas namun jumlah penurunan petani gurem hanya sebesar $29,75 \%$ pada tahun $2013^{20}$. Angka ini lebih rendah dibandingkan dengan rata-rata penurunan petani gurem di Kabupaten Jember sebesar $33,62 \%{ }^{20}$. Desa Nogosari diambil sebagai tempat penelitian karena merupakan wilayah 
dengan luas pertanian paling besar di Kecamatan Rambipuji Kabupaten Jember, namun sebanyak $31 \%$ merupakan petani gurem $^{21}$. Berdasarkan latar belakang peneliti tertarik untuk melihat adakah hubungan faktor akses ekonomi rumah tangga petani gurem yang terdiri dari pendapatan, pengeluaran, proporsi pengeluaran pangan rumah tangga dengan tingkat ketahanan pangan rumah tangga petani gurem. Tujuan dari penelitian adalah mengetahui akses ekonomi yang berhubungan dengan ketahanan pangan rumah tangga petani gurem Desa Nogosari Kecamatan Rambipuji Kabupaten Jember.

\section{METODE}

Penelitian ini menggunakan desain cross sectional yang dilakukan di lokasi penelitian dengan alasan Desa Nogosari merupakan desa yang memiliki jumlah petani terbanyak dan luas wilayah pertanian paling luas di Kecamatan Rambipuji. Populasi penelitian (N) adalah semua petani gurem yang tercatat di Rencana Definitif Kebutuhan Kelompok (RDKK) Pupuk Bersubsidi Desa Nogosari yang berjumlah 349. Besar sampel (n) yang digunakan sebesar 51 rumah tangga petani yang telah memenuhi syarat inklusi yakni petani gurem yang dipilih bukan berada dalam satu rumah tangga yang sama. Sampel kemudian dibagi dengan metode propotional sampling dan pengambilan sampel diambil dengan cara propotional random sampling. Pengambilan sampel diambil secara acak pada masing-masing kelompok tani. Rumah tangga yang menjadi sampel penelitian telah mewakili petani gurem dari 7 kelompok tani di Desa Nogosari.

Penelitian telah lolos uji etik dengan nomor 173-KEPK dari komisi etik Fakultas Kesehatan Masyarakat Universitas Airlangga. Data dikumpulan dengan data primer dan sekunder. Data primer diambil melalui wawancara yang terstruktur dengan kuisioner. Sedangkan data sekunder digunakan untuk mengetahui jumlah rumah tangga petani gurem yang diambil dari data RDKK (Rencana Definitif Kebutuhan Kelompok) Desa Nogosari Kecamatan Rambipuji Kabupaten Jember.
Penilaian status ketahanan pangan rumah tangga menggunakan kuisioner United State Household Food Security Survey Modul (USHFSSM) untuk mengetahui gambaran ketahanan pangan baik yang terjadi saat musim panen maupun tidak dalam satu tahun terakhir. Kuisioner tersebut dapat melihat kerawanan pangan dengan derajat yang lebih parah dengan mempertimbangkan rumah tangga yang memiliki anak ( $<18$ tahun) dan tidak. Data disajikan dengan tabel frekuensi dan tabulasi silang antara akses ekonomi dan status ketahanan pangan rumah tangga. Analisis menggunakan uji statistik spearman dan chi-square untuk mengetahui apakah ada hubungan antara faktor akses ekonomi dengan tingkat ketahanan pangan rumah tangga dengan nilai $\alpha=0,05$. Pendapatan dan pengeluaran pangan rumah tangga dikategorikan menurut kuintil sedangkan proporsi pengeluaran pangan dihitung dari rasio pengeluaran pangan terhadap total pengeluaran rumah dan dikategorikan rendah bila proporsi pengeluaran pangan $<60 \%$, tinggi bila $\geq 60 \%{ }^{[23]}$.

\section{HASIL DAN PEMBAHASAN}

Akses ekonomi rumah tangga petani gurem dapat dilihat dari pendapatan, pengeluaran dan proporsi pangan rumah tangga ${ }^{24}$. Pendapatan rumah tangga didapatkan baik dari usaha tani (on farm) dan non usaha tani (off farm). Sedangkan pengeluaran pangan didapatkan dari total pengeluaran pangan rumah tangga petani gurem baik pangan dan non pangan dalam sebulan terakhir. Proporsi pangan adalah proporsi pengeluaran yang dikeluarkan rumah tangga untuk memenuhi kebutuhan pangan rumah tangga petani gurem. Penilaian indikator status ketahanan pangan rumah tangga petani gurem menggunakan indikator US-HFSSM yang kemudian dikategorikan empat kategori tahan pangan, rawan pangan tanpa kelaparan, rawan pangan dengan kelaparan sedang, dan rawan pangan dengan kelaparan berat. Distribusi akses ekonomi dan status ketahanan pangan rumah tangga petani gurem dapat dilihat pada Tabel 1 . 
Tabel 1. Distribusi Responden Menurut Akses Ekonomi dan Status Ketahanan Pangan Rumah Tangga Petani Gurem di Desa Nogosari Kecamatan Rambipuji Kabupaten Jember

\begin{tabular}{lcc}
\hline \multicolumn{1}{c}{ Variabel } & Jumlah & $\begin{array}{c}\text { Presentase } \\
\%\end{array}$ \\
\hline $\begin{array}{l}\text { Pendapatan } \\
\text { Kuintil 1 }\end{array}$ & 5 & 9,8 \\
Kuintil 2 & 5 & 9,8 \\
Kuintil 3 & 5 & 9,8 \\
Kuintil 4 & 7 & 13,7 \\
Kuintil 5 & 29 & 56,9 \\
Pengeluaran & & \\
Kuintil 1 & 5 & 9,8 \\
Kuintil 2 & 5 & 9,8 \\
Kuintil 3 & 5 & 9,8 \\
Kuintil 4 & 6 & 11,8 \\
Kuintil 5 & 30 & 58,8 \\
Proporsi pengeluaran pangan & & \\
S60\% & 26 & 54,9 \\
$>60 \%$ & 23 & 45,1 \\
Status Ketahanan Pangan & & \\
Tahan Pangan & 12 & 23,5 \\
Rawan Pangan Tanpa Kelaparan & 15 & 29,4 \\
Rawan Pangan dengan Kelaparan Sedang & 13 & 25,5 \\
Rawan Pangan dengan Kelaparan Parah & 11 & 21,6 \\
\hline
\end{tabular}

Pada tabel 1 menunjukkan bahwa sebagian besar $(56,9 \%)$ pendapatan rumah tangga berada pada kuintil 5 yakni berkisar antara Rp 1.225.001 - Rp 3.000.000. Pendapatan yang tinggi pada sebagian besar rumah tangga dikarenakan sebagian rumah tangga menambah pendapatannya dengan pekerjaan sampingan yakni buruh bangunan, pengrajin, berdagang, beternak dan berkebun. Pekerjaan sampingan yang dilakukan oleh petani sebagian besar mengandalkan tenaga. Hal ini dikarenakan pekerjaan yang tidak menggunakan tenaga membutuhkan tingkat pendidikan formal yang lebih tinggi. Petani cenderung tidak menggunakan peluang bekerja di luar sektor pertanian karena terhalang faktor rendahnya pendidikan sehingga tidak mampu meningkatkan pendapatan rumah tangga ${ }^{25}$. Selain itu, petani kurang sadar akan adanya potensi di luar pertanian karena cenderung ingin meneruskan pekerjaan dan tidak mempertimbangkan keuntungan yang lebih luas ${ }^{25}$.
Rendahnya tingkat pendidikan formal pada petani menurut hasil wawancara disebabkan oleh rendahnya kesadaran dan akses orangtua petani gurem terhadap pendidikan formal. Pendidikan formal sebagian besar hanya sampai tamatan SD karena menurut informasi responden kemampuan membaca, menulis dan berhitung dianggap sudah cukup sebagai modal bekerja. Menurut Mukhlis (2011) petani lebih memilik menghabiskan waktu untuk bekerja sehingga tidak memiliki banyak waktu untuk menempuh pendidikan yang lebih tinggi ${ }^{26}$.

Banyaknya pendapatan yang berada pada kuintil 5 juga dipengaruhi oleh besar keluarga. Sebagian anggota keluarga petani yang berada pada usia yang produktif akan mempengaruhi tingkat pendapatan yang akan menambah kesejahteraan petani ${ }^{27}$. Berbeda bila jumlah anggota keluarga banyak akan berpengaruh pada jumlah pendapatan rumah tangga dengan mengakibatkan tingkat kesejahteraan rumah tangga yang menurun 
akibat banyaknya tanggungan dalam keluarga ${ }^{28}$.

Besarnya pendapatan pangan yang sebagian $(58,8 \%)$ berada pada kuintil 5 tidak menjamin bahwa kesejahteran petani meningkat. Hal ini disebabkan karena ternyata sebagian rumah tangga petani gurem memiliki total pengeluaran pangan rumah tangga yang berada pada kuintil 5 yakni berada pada kisaran antara Rp 1.173.129 - Rp 3.000.000. Pengeluaran rumah tangga didapatkan dari total pengeluaran rumah tangga petani gurem baik pangan dan non pangan. Pengeluaran pangan termasuk dalam pengeluaran baik pangan yang diproduksi sendiri oleh rumah tangga pertanian maupun yang bukan. Tingginya pengeluaran rumah tangga juga digunakan untuk biaya produksi dalam usaha tani dari biaya benih, pupuk, peptisida, dan biaya lainnya. Ditambah lagi bila lahan yang dimiliki bukan miliknya. Menurut hasil wawancara tidak semua lahan petani adalah milik sendiri sebagian besar mereka adalah penyewa. Sebagai petani penyewa pengeluaran rumah tangga digunakan untuk membayar biaya sewa sehingga beban biaya produksi menjadi lebih tinggi dan membuat pengeluaran rumah tangga menjadi lebih besar $^{29}$.

Proporsi pengeluaran pangan dihitung dari persentase pengeluaran pangan dibanding dengan pengeluaran total rumah tangga petani. Semakin tinggi proporsi pengeluaran pangan dibanding non pangan dapat menunjukkan ketidaksejahteraan rumah tangga petani ${ }^{30}$. Akses ekonomi yang baik akan membuat petani sejahtera dan akan berpengaruh pada kuantitas dan kualitas konsumsi yang mereka konsumsi ${ }^{30}$. Menurut hasil penelitian dapat diketahui bahwa sebagian besar $(54,9 \%)$ rumah tangga petani gurem memiliki proporsi pengeluaran pangan $<60 \%$. Hal ini menunjukkan sebagian besar rumah tangga petani gurem memiliki proposi pengeluaran pangan yang rendah dibandingkan non pangan yang artinya kesejahteraan petani gurem sebagian besar baik. Menurut Marwanti (2002) proporsi pengeluaran pangan menunjukkan bahwa dalam kondisi terbatas biasanya rumah tangga akan mendahulukan kebutuhan yang mendesak yakni pangan sehingga semakin rendah proporsi pengeluaran pangan maka tingkat kesejahteraan penduduk semakin rendah dan semakin luas kemiskinan ${ }^{31}$.

Berdasaran penilaian status ketahanan pangan rumah tangga dengan menggunakan US-HFSSM didapatkan hasil bahwa hanya $23,5 \%$ yang berada pada tahan pangan. Sebagian besar $(76,5 \%)$ responden mengalami kerawanan pangan dengan tingkatan yang berbeda. Rumah tangga yang mengalami kerawanan pangan sebagian besar hanya mengalami kerawanan tanpa kelaparan (29,4\%). Hal ini menunjukkan bahwa keluarga yang berusia rentan (anak-anak) masih menjadi prioritas dalam penentuan pengeluaran rumah tangga. Menurut hasil wawancara sebagian besar rumah tangga sering merasa cemas kekurangan makanan karena tidak cukup uang. Kondisi rawan yang dialami petani khususnya petani gurem dikarenakan keterbatasan lahan yang membuat kesejahteraan petani menjadi menurun $^{32}$. Hal ini sejalan dengan penelitian Tanziha (2010) yang menyebutkan bahwa petani yang merupakan petani gurem memiliki risiko mengalami rawan pangan lebih tinggi daripada petani non gurem ${ }^{33}$.

Berdasarkan grafik 1, setelah melakukan analisis dengan uji spearman didapatkan nilai $p$-value $<0,001$ menunjukkan terdapat hubungan yang negatif antara pendapatan petani gurem dengan status ketahanan pangan petani gurem. Penelitian ini menunjukkan bahwa ketika pendapatan petani gurem semakin besar maka skor kerawanan pangan semakin rendah sehingga rumah tangga berada pada skondisi tahan pangan. Hal ini sejalan dengan penelitian terdahulu yang menyebutkan peingkatan pendapatan petani berlahan kecil akan berdampak pada konsumsi makanan yang lebih beragam, serta meningkatkan akses terhadap makanan yang lebih bergizi dan meningkatkan pengeluaran pangan non pangan sehingga akan meningkatkan status ketahanan pangan dan gizi ${ }^{34}$. Menurut Sari dan Andrias (2013) faktor yang mempengaruhi status ketahanan pangan rumah tangga adalah besar kecilnya pendapatan rumah tangga ${ }^{35}$. Pendapatan petani gurem setiap 
musimnya tidak selalu sama sedangkan pengeluaran konsumsi rumah tangga juga tidak dapat diprediksi dan sewaktu-waktu akan terjadi kenaikan harga pada konsumsi rumah tangga maupun untuk produksi pertanian $^{13}$. Semakin meningkatnya pendapatan pada petani akan membuat rumah tangga petani lebih banyak mengonsumsi pangan selain pangan yang diproduksi sendiri ${ }^{17}$. Hal ini dikarenakan sebagaian besar rumah tangga petani gurem yang menjadi subyek penelituan memiliki sifat semi subsisten yang artinya apa yang diproduksi oleh petani sebagian besar untuk dikonsumsi rumah tangga sendiri dan sebagian lagi dijual untuk keperluan lainnya.

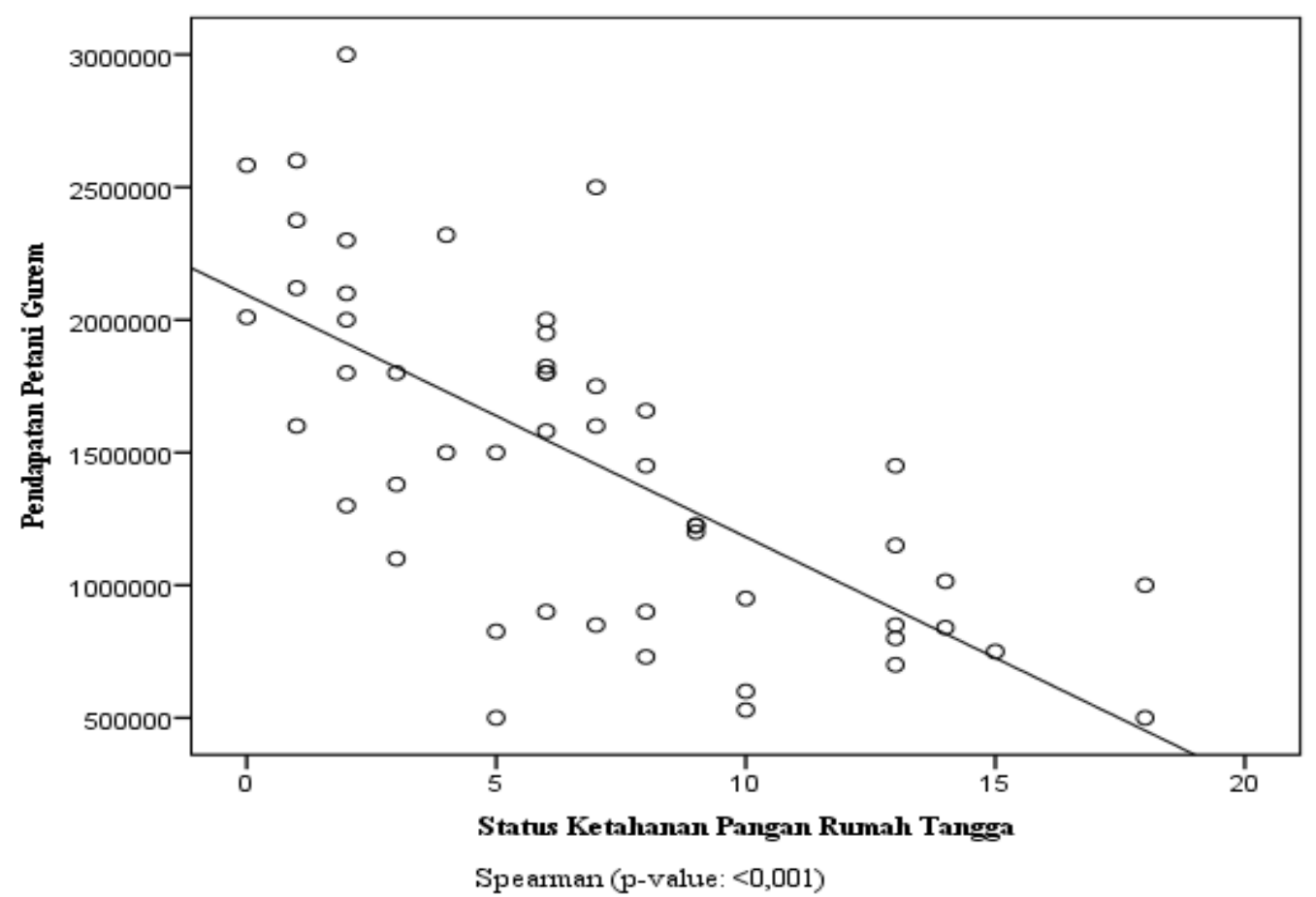

Grafik 1. Status Ketahanan Pangan menurut Pendapatan Rumah Tangga Petani Gurem

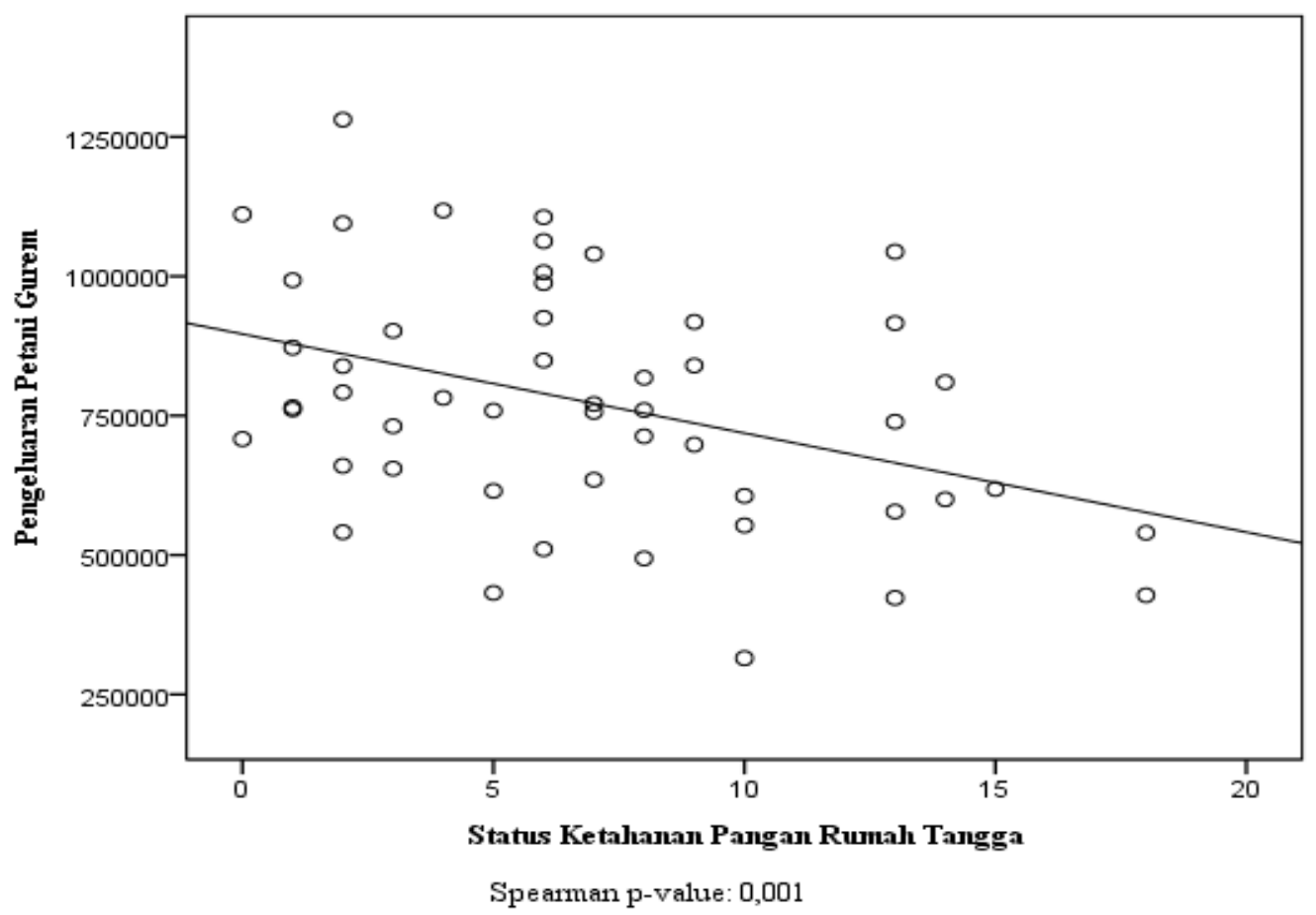

C2017. Amalia dan Mahmudiono. Open access under CC BY - SA license. Received 15-7-2017, Accepted 3-8-2017, Published online: 23-10-2017. 
Grafik 2. Status Ketahanan Pangan menurut Pengeluaran Pangan Rumah Tangga Petani Gurem

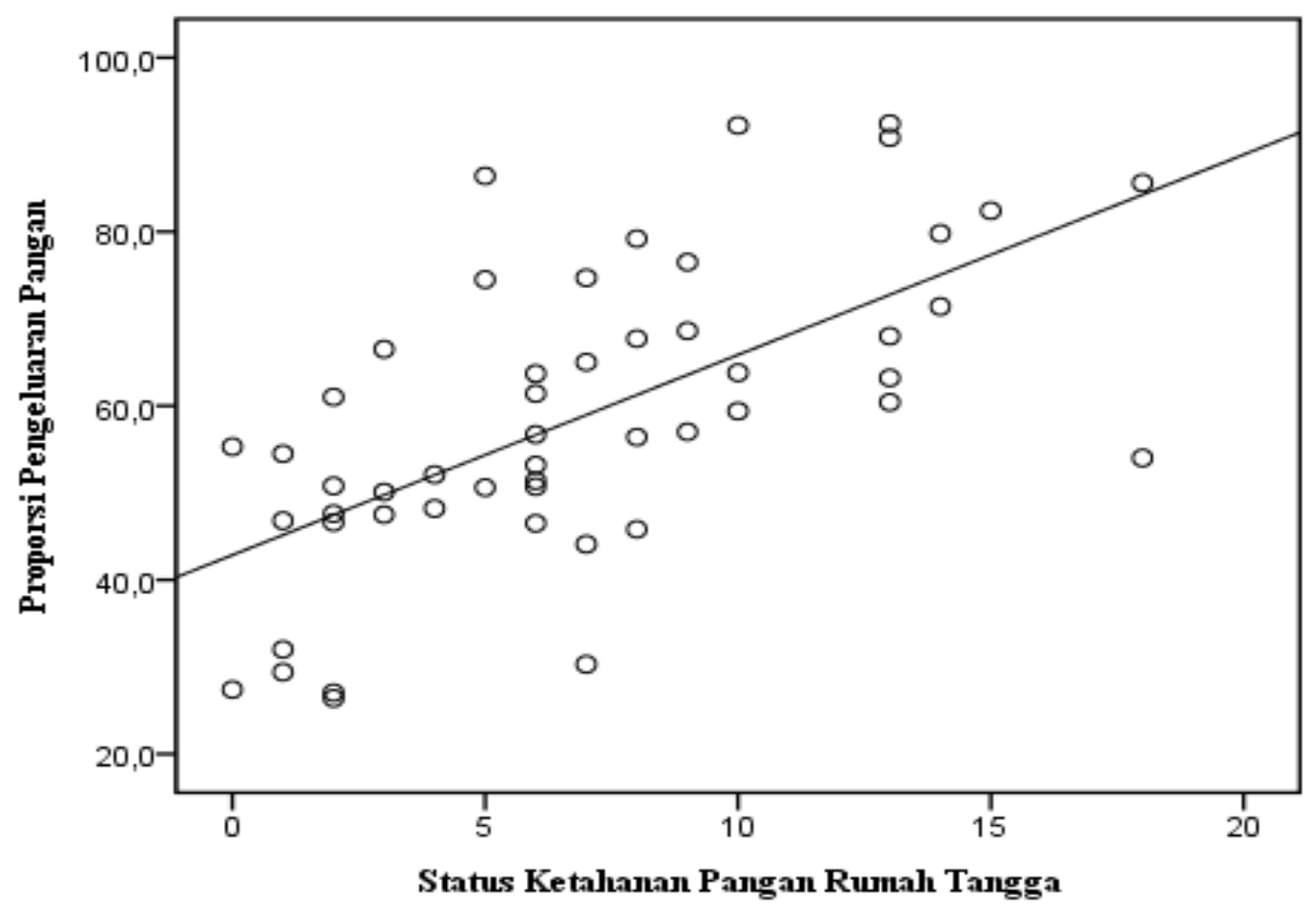

Chi-Square (p-value: 0,001)

Grafik 3. Status Ketahanan Pangan menurut Proporsi Pengeluaran Pangan Rumah Tangga Petani Gurem

Berdasarkan Grafik 2, terdapat korelasi negatif antara pengeluaran dengan status ketahanan pangan rumah tangga petani gurem dengan nilai $p$-value $0,001(\alpha=0,005)$. Artinya semakin tinggi pengeluaran pangan maka skor US-HFSSM semakin rendah dan membuat rumah tangga berada pada kodisi tahan pangan. Hal ini sejalan dengan penelitian Herdiana (2009) yang menyebutkan adanya hubungan antara pengeluaran rumah tangga dengan status ketahanan pangan rumah tangga ${ }^{36}$. Pengeluaran per kapita per bulannya akan berpengaruh pada tingkat konsumsi energi dan protein, dimana semakin tinggi pengeluaran per kapita per bulan maka akan lebih tinggi peluang untuk konsumsi energi dan protein dibandingkan dengan pengeluaran per kapita per bulan yang rendah $^{37}$. Hal ini menujukkan bahwa kemampuan daya beli rumah tangga yang tercermin dari pengeluaran rumah tangga akan mempengaruhi kebutuhan konsumsi pangan rumah tangga ${ }^{30}$.

Berdasarkan Grafik $3, \begin{array}{r}\text { indikator } \\ \text { dengan }\end{array}$
proporsi pengeluaran pangan $\begin{aligned} & \text { didapatkan nilai } p- \\ & \text { melakukan uji chi-square didan }\end{aligned}$
value 0,001 yang menunjukkan adanya
korelasi positif antara proporsi pengeluaran
pangan dengan status ketahanan pangan
petani gurem. Artinya adalah bila proporsi
pangan semakin tinggi maka rumah tangga
berpotensi mengalami rawan pangan. Hal ini
diperkuat dengan penelitian Firdaus (2013)
yang menyebutkan bahwa kuantitas pangan
yang dipenuhi rumah tangga akan terbatas
sedangkan kebutuhan non pangan yang
termasuk kualitas dari makanan yang
dikonsumsi tidak terbatas sehingga bila
proporsi pengeluaran non pangan lebih tinggi
maka rumah tangga tersebut semakin
sejahtera ${ }^{38}$. Dalam keadaan miskin
pengeluaran rumah tangga akan lebih banyak
pada pengeluaran pangan dibanding non
pangan sehingga akan berpengaruh pada
pemenuhan gizi dan status ketahanan
pangan ${ }^{39}$.


Dari berbagai akses ekonomi ternyata seluruh variabel baik pendapatan, pengeluaran dan proporsi pengeluaran memiliki hubungan dengan status ketahanan pangan petani gurem. Kelebihan dari penelitian ini adalah penelitian fokus mempelajari akses ekonomi petani gurem dimana mereka mendominasi masyarakat miskin di Indonesia. Penelitian penilaian status ketahanan pangan petani gurem menjadi penelitian yang baru di Indonesia. Petani gurem bekerja secara semi subsisten artinya mereka menjadi produsen sekaligus konsumen. Petani dihadapkan bagaimana mereka mempertahankan ketahanan pangan individu, rumah tangga serta nasional [40]. Kelebihan setelah mempelajari hubungan akses ekonomi pada petani gurem diharapkan menambah wawasan akan jalan keluar untuk meningkatkan ketahanan pangan secara nasional dan mengentas kemiskinan di Indonesia. Pertumbuhan ekonomi pada pertanian diharapkan dapat meningkatkan ekonomi di Indonesia. Kekurangan dari penelitian ini adalah pada penelitian tidak mempelajari aset petani secara keseluruhan karena beberapa aset baru diketahui saat di lapangan.

\section{KESIMPULAN}

Terdapat hubungan antara akses ekonomi yang meliputi pendapatan, total pengeluaran, dan proporsi pengeluaran pangan dengan status ketahanan pangan rumah tangga petani gurem di Desa Nogosari Kecamatan Rambipuji Kabupaten Jember.

Pemerintah diharapkan dapat menambah akses ekonomi petani dengan cara meningkatan pendapatan petani melalui jaminan hasil panen melalui akses pasar bagi petani agar diterima pasar lebih luas. Peningkatan konsumsi pangan juga bisa melalui KRPL (Kawasan Rumah Pangan Lestari) agar rumah tangga petani dapat menyediakan kebutuhan rumah tangga secara mandiri dan konsumsi menjadi lebih beragam. Penelitian lebih lanjut diharapkan dapat meneliti lebih jauh faktor apa saja yang dominan dalam akses ekonomi petani gurem dan mempertimbangkan aset yang dimiliki rumah tangga petani gurem.

\section{ACKNOWLEDGEMENT}

Penghargaan diberikan penulis kepada seluruh staf pengajar program studi sarjana ilmu gizi Universitas Airlangga atas bimbingan dan dukungan yang telah diberikan.

\section{REFERENSI}

1. Undang-undang Republik Indonesia Nomor 7 Tahun 1996 tentang Pangan. Jakarta: Sekretariat Negara;1996.

2. Sari, Mardiana R. Faktor-faktor yang mempengaruhi kerawanan pangan rumah tangga miskin di Desa Wiru Kecamatan Bringin Kabupaten Semarang.Skripsi. Semarang: Fakultas Ekonomi Universitas Negeri Semarang; 2009.

3. Badan Pusat Statistik. Profil kemiskinan di Indonesia. Jakarta: BPS; 2016.

4. Badan Pusat Statistik. Kharateristik rumah tangga miskin. Jakarta: BPS; 2014.

5. Sunandi, D. Laporan Pembangunan dunia 2008: Pertanian untuk pembangunan world development report 2008: Agriculture for development. Penerbit Salemba Empat: Jakarta; 2008.

6. Ramadhan, A. Strategi survival petani dalam pengolahan lahan Pasir: studi kasus tiga petani gurem di lahan pasir Dusun Bugel II, Kulon Progo. Skripsi. Yogyakarta: Fakultas IImu Budaya Universitas Gajah Mada; 2014.

7. Sumrah. Kemiskinan dan Strategi Kelangsungan Hidup. Tesis. Bulukumba: Fakultas Pascasarjana; 2008

8. Badan Pusat Statistik. Laporan hasil sensus pertanian 2013 (Pencacahan lengkap), Jakarta: BPS; 2013.

9. Ariani, M. Memperkuat kemampuan swasembadaya pangan: upaya peningkatan akses pangan masyarakat mendukung ketahanan pangan. Jakarta: IAAD Press; 2014.

10. Septya, F. 2013. Peranan PUAP dan raskin dalam perilaku ekonomi dan ketahanan 
pangan rumahtangga petani di Kecamatan Sadang Kabupaten Kebumen. Tesis. Bogor: Pascasarjana Institut Pertanian Bogor; 2013

11. Kirimi L, Gitau R, Olunga M. Household food Security and Commercialization Among Smallholder Farmers in Kenya. Paper prepared for The $4^{\text {th }}$ International Conference of The African Association of Agricultural Economists; 2013 April; Naerobi, Kenya. p. 1-19.

12. Soleh, M. Kemiskinan: Telaah dari beberapa situasi penanggulangan kemiskinan.Yogyakarta: Fakultas IImu Sosial dan Ekonomi Universitas Negri; 2010.

13. Wahed, M. Pengaruh luas lahan, produksi, ketahanan pangan dan harga gabah terhadap kesejahteraan petani padi di Kabupaten Pasuruan. JESP 2015; 7(1): 68-74.

14. Irawan B dan Ening A .Dinamika kebijakan dan ketersediaan lahan pertanian: Laporan hasil penelitian. Bogor: Pusat sosial ekonomi dan kebijakan pertanian; 2015.

15. Sukiyono K, Widiono S, Cahyadinata dan Sriyoto. Kajian tentang local concept ketahanan pangan dan probalitas terjadinya kerawanan pangan rumah tangga (Studi pada rumah tangga nelayan dan petani padi di Kabupaten Mukomuko Provinsi Bengkulu). Skripsi. Begkulu: Fakultas Pertanian Universitas Bengkulu; 2009.

16. Firdaus M, Apriliani T dan Wijaya, Rizky A. Pengeluaran rumah tangga nelayan dan kaitannya dengan kemiskinan (kasus di Desa Ketapang Barat, Kabupaten Sampang Madura. Jurnal SOSEK KP 2013; 8(1):1

17. Agbola PO. Faktor influencing food insecurity among small farmers in Nigeria. African Journal of Agricultural Research 2014; 9(27): 2104-10.

18. Dewan Ketahanan Pangan dan World Food Program. Peta Kerawanan Pangan Indonesia (Atlas of Food Insecurity in Indonesia). Jakarta: Departemen Pertanian; 2015.
19. Kominfo Jatim 2011, Jember Berpotensi Jadi Kawasan Industri Agraris Jember Berpotensi Jadi Kawasan Industri Agraris, Tersedia di http://kominfo.jatimprov.go.id/read/ kiprah-daerah/694. [Diakses 10 Oktober 2016].

20. Badan Pusat Statistik. Statistik Lahan Pertanian Tahun 2009-2013. Jakarta: BPS; 2014.

21. _. Laporan Hasil Sensus Pertanian 2013: Hasil Pencacahan Lengkap Kabupaten Jember. Jember: BPS; 2014.

22. Lameshow, SK and Lwanga. Sample size determination in healtth studies: a pratical manual S.K Lwanga and S. Lameshow.Geneva: World Health Organization; 1991.

23. Johson $U$ and Toole D. Household Food Security and Nutrition: A Conceptual Analysis Mimeo. Newyork: UNICEF; 1991.

24. Nilasari A, Harisudin M, Widiyanto. Analisis hubungan antara pendapatan dengan proporsi pengeluaran pangan dan kecukupan gizi rumah tangga petani Kabupaten Cilacap. Jurnal AGRISTA 2013;1(1):1-12.

25. Yunita, Basita G, Pang SA, Djoko S, Siti A. Ketahanan pangan dan mekanisme koping rumah tangga petani padi sawah lebak berdasarkan status kepemilikan lahan. Jurnal Ilmu Keluarga dan Konsumen 2011; 4(1):21-29.

26. Mukhlis, A. Faktor-faktor yang mempengaruhi rendahnya tingkat pendidikan masyarakat Desa Dieng Wetan Kecamatan Kejajar Kabupaten Wonosobo. Skripsi. Semarang: Fakultas Ilmu Sosial Universitas Negeri Semarang; 2011.

27. Prasetyoningrom F, Rahayu ES. Analisis pola konsumsi rumah tangga petani jagung di Kabupaten Grobongan. Agric 2016; 28(1)(2):41-54.

28. Habeahan, E. Gambaran ketahanan pangan rumah tangga petani padi di Desa Maligas Tongah Kecamatan Tanah Jawa Kabupaten Simalungun. Skripsi. Medan: Fakultas Kesehatan Masyarakat Universitas Sumatera Utara; 2015. 
29. Ekowati $T$ dan Prasetyo E. Sistem penguasaan dan produktivitas lahan usahatani padi di Desa Candi, Kecamatan Karnganyar, Kabupaten Kebumen. Prosiding Semnas Agribisnis. Semarang; 2015. p. 399-404.

30. Yudaningrum, A. Analisis hubungan proporsi pengeluaran dan konsumsi pangan dengan ketahanan pangan rumah tangga petani di Kabupaten Kulon Progo. Skripsi. Semarang: Fakultas Pertanian Universitas Sebelas Maret; 2011

31. Marwanti, S. Pola pengeluaran untuk Konsumsi Pangan Gizi Penduduk Indonesia (Analisis Data Susenas 1999). Carakatani XVII 2002.

32. Wahed M. Pengaruh luas lahan, produksi, ketahanan pangan dan harga gabah terhadap kesejahteraan petani padi di Kabupaten Pasuruan. JESP 2015; 7(1):6874.

33. Tanziha I, Sumarti T, Ariani M. Model penguatan modal komunitas pertanian dalam upaya pencegahan dan penanggulagan kelaparan di Provinsi Banten. Bogor: LPPM IPB; 2010.

34. Diola BM, Deret $H$, Morel J, Vechet E, Kiaya V. Enhancing the role of smallholder farmers in achieving suistanable food and nutrition security: Rome: FAO and WHO:2013.
35. Sari, AK dan Andrias DR. Faktor sosial ekonomi yang berhubungan dengan sketahanan pangan rumah tangga nelayan perkotaan di surabaya. Media Gizi Indonesia 2013; 9(1):54-59.

36. Herdiana, E. Analisis jalur faktor-faktor yang mempengaruhi ketahanan pangan rumah tangga di Kabupaten Lebak, Provinsi Banten. Skripsi. Bogor: Fakultas Ekologi Manusia Institut Pertanian Bogor; 2009.

37. Hidayati, K. Dukungan sosial dan food coping strategy serta hubunganya dengan tingkat konsumsi energi dan protein pada keluarga nelayan. Skripsi. Bogor: Fakultas Ekologi Manusia Institut Pertanian Bogor: 2008.

38. Firdaus MT, Apriliani dan Wijaya RA. Pengeluaran rumah tangga nelayan dan kaitannya denga kemiskinan (kasus di Desa Ketapang Barat, Kabupaten Sampang Madura). Jakarta: Jurnal SOSEK KP; 2013.

39. Arida A, Sofyan, Fadhiela K. Analisis ketahanan pangan rumah tangga berdasarkan proporsi pengeluaran pangan dan konsumsi energi. Agrisep 2015; 16(1): 20-34.

40. Soetrisno, L. Paradigma baru pembangunan pertanian sebuah tinjauan sosiologis. Yogyakarta: Kanisius; 2002. 